\title{
They Sought a Country
}




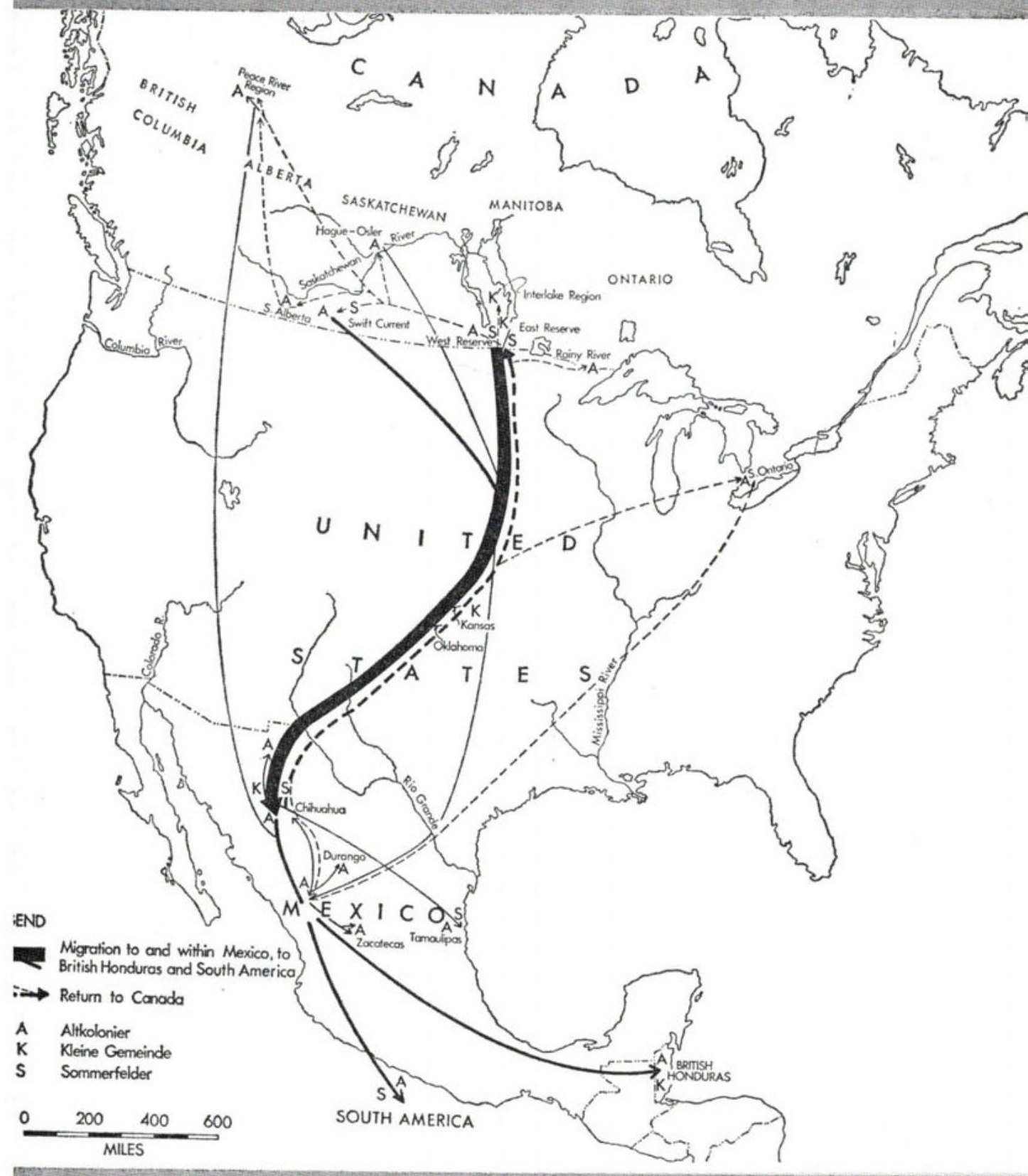

Mennonite migration to, from, and within Mexico 


\section{They Sought a Country}

\section{MENNONITE \\ COLONIZATION \\ IN MEXICO}

With an Appendix on Mennonite

Colonization in British Honduras

\section{Harry Leonard Sawatzky}

UNIVERSITY OF CALIFORNIA PRESS

Berkeley, Los Angeles, London 1971 
University of California Press

Berkeley and Los Angeles, California

University of California Press, Ltd.

London, England

Copyright (C 1971, by

The Regents of the University of California

ISBN: 0-520-01704-8

Library of Congress Catalog Card Number: 78-92673

Printed in the United States of America 
To Johann and Elizabeth Sawatzky 
